\title{
THE INFLUENCE OF INDIVIDUAL DIFFERENCES ON TECHNICAL CREATIVITY IN SLOVENIAN K-9 STUDENTS
}

Stanislav AVSEC, University of Ljubljana, Faculty of Education, Slovenia Klavdija MODIC, University of Ljubljana, Faculty of Education, Slovenia

Received: 26. 6. 2017/ Accepted: 24. 9. 2017

Type of article: original research

DOI: $10.5507 /$ jtie.2017.021

Abstract: This study aims to verify and understand the effect of individual differences on technical creativity in Slovenian K-9 students. Students' learning styles and their attitudes towards technology and engineering, which might have implications in students for teaching and developing creativity, were investigated. Despite of several approaches to teaching and of curriculum learning standards in technical creativity, technology education courses still suffer from creativity development needed for future creation of new technologies, and for inventions of products. For the purpose of this study, an effective sample of $n=177$ secondary school students in grade 6 and in grade 9 was collected. An empirical research design was followed. A recently developed DSLI learning style inventory was used for measuring learning styles, while student attitude towards technology and engineering was surveyed with 25-item test. Students' creative potential was measured with a standardised test of creative thinking-divergent production. The results of the study on creativity show no significant $(p>0.05)$ differences in creative potential between sixth- and ninth-graders. Moreover, interest for technology is not particularly positive for both groups of students, when a lack of technology identification in sixth-graders appears significantly $(p<0.05)$. Students' learning styles were found as significant $(p<0.05)$ predictors in students creative potential. Students still feel perplexed with technology and the current design and technology curriculum might not markedly influence student decision to pursuit careers in technology and engineering.

Key words: technology education, technical creativity, learning styles, attitude.

\section{VLIV INDIVIDUÁLNÍCH ODLIŠNOSTÍ U ŽÁKŮ ZÁKLADNÍCH ŠKOL VE SLOVINSKU NA TECHNICKOU KREATIVITU}

Abstrakt: Cílem studie bylo ověrit vliv individuálních odlišností na technickou kreativitu. Byly zkoumány učebni styly žáků a jejich postoje k různým technickým oblastem (technika, technologie, konstruování). Podařilo se mj. zjistit, že žáci mezi 6. - 9. ročníkem nevykazuji žádné významné rozdily v tvưrčím potenciálu.

Klíčová slova: technická výchova, technická tvořivost, učební styly, postoj.

* Author for correspondence: Stanislav.Avsec@pef.uni-lj.si 


\section{Introduction}

Creativity is an important influencer of the sustainable development of any organisation, and along with innovation, it facilitates the transformation of individual learning roles into desired future levels (Avsec \& Šinigoj, 2016; Cropley, 2015). Moreover, creativity was found as a top three employability skill in $21^{\text {st }}$ century (Barbot, Besancon, \& Lubart, 2016), and it is emphasized in almost any subject matter curriculum in K-9 education, including in curriculums of technology education. The real intent for technology education is to prepare students to be technological literate and able to cope with rapidly developing technological world not only as a user but also as a creative contributor or designer (McGlashan, 2017). Despite of several curriculum learning standards of technical creativity, and of several active approaches to teaching and learning, the technology education courses still suffer from creativity development (Avsec \& Šinigoj, 2016).

The recent studies and experiences show that the school atmosphere and traditional teaching do not enhance creativity and often even decline it (Avsec \& Šinigoj, 2016; McGlashan, 2017). A system of education is organized as a rigid and solid system, focused only on learning outcomes assessed with marks, which are obtained gradually throughout the study year. Students must follow this algorithmic way, and situations where student's creative potential might takes place are rather seldom. Assessment of learning outcomes is highly demanded and teachers rather avoid assessing subjects where outcomes are heterogeneous, multifaceted as technical creativity is. Creativity in Slovenian Primary school (Key Stage K1-9) is not encouraged at all teaching subjects, therefore a role of Design and technology (DT) subject matter with its methods of active, learner-centred work and learning seem to be crucial. Creativity at DT should be strengthened primarily by setting open problems, finding product improvements and new functionalities, extending the scope and the range of use of the product.

In technology education, along with technological literacy as the most important outcome, a creative ability should be developed, and it also reflects in the different technical products/artefacts created by students. Moreover, Kallio and Metsarinne (2017) stated that experiencing learner-centred learning predicts positive attitudes towards DT subject matter. Students are more successful also in production exercises to create new products or processes (Kallio and Metsarine, 2017), which might reflects technical creativity as internal driven potential for proactive problem solving (Avsec and Šinigoj, 2016). Social learning and other-scaffolding learning might predict effective technical products, technological knowledge, and skills as DT learning outcomes (Kallio and Metsarinne, 2017).

Students have different levels of motivation, different attitude towards design and technology (Ardies, De Maeyer, Gijbels, \& van Keulen, 2015) and different reactions to learning environments, including subject matter contents and practices (SzewczykZakrzewska \& Avsec, 2016). Moreover, at least three facets of student diversity must be considered, namely: learning styles, approaches to learning and orientations to studying, and intellectual development (Felder and Brent, 2005). We should map first students' abilities, and attitude to encourage every single student to launch dynamism of learning styles in order to enhance social learning as scaffolding learning of evidence-based practise. Students will improve if they think about how they learn (Szewczyk-Zakrzewska \& Avsec, 2016). Learning depends on what is being taught, how students prior-knowledge is, how motivated they are in scaffolding learning. Thus, teachers must understand student 
differences and they must be able to adjust learning/teaching methods to meet and to boost diverse learning needs of all of their students. Effective teacher utilizes information of students learning styles to differentiate instruction with focusing on the content, students' experiences and perception toward content or subject matter, on students' motivation to learning (Avsec \& Šinigoj, 2016; Ardies et al, 2015). Attitudes towards technology, however, consist of different sub-aspects such as (1) affective-emotions or feelings, (2) cognitive-beliefs or opinions held consciously, (3) conative-inclination for action, and (4) evaluative-positive or negative response to stimuli, and research focussing on these different aspects in an integrated manner is needed in order to provide insights into how attitudes are formed.

In the present study we aim to verify and understand the effect of individual differences on technical creativity in Slovenian K-9 students. Differences relate to the differences between students and different groups of students. Regarding the different problems suggested above, a background of technology education and creativity is given in the following section.

\section{Technology education and creativity}

Slovenian K-9 technology education insight, teachers' backgrounds and role, and students' personality and behaviour are described in the following subsections. All aforementioned influencers might be decisive for creativity development.

Despite the critical importance of technology education in Europe and wider, a mismatch between the technological knowledge, skills, and attitudes delivered by education and training systems and those required by the labour market has been reported in several countries also in Slovenia, where the latest school reform implemented in 1996 resulted in a marked decrease in the number of hours allotted to subject matter relating to design, technology and engineering in primary schools. Just $1.73 \%$ of hours in total taught time are allocated to teaching compulsory technology education subjects in primary schools (K-9), reflecting the lowest prioritisation of technology education across Europe (Avsec \& Jamšek, 2016). Along with old-fashion technology education curriculum it can douse students' technical creativity and students' interest for technology. Correspondingly, a number of students enrolled in secondary vocational and technical school decrease from year to year. This trend has been seen also around the Europe, but some countries started with technology education reconstruction, also some changes are proposed and centred on International Technology and Engineering Educators Association standards for technological literacy, where integrated performance-approach to study technology is suggested as an appropriate (Dostal \& Prachagool, 2016).

Primary school technology education (K-9) in Slovenia is two-sided. At the elementary level of primary school $(\mathrm{K}-5)$ technology education is part of an integrated learning domain called Natural Sciences and Technology. In K-3 education, 24 school periods ( 45 minutes) per year are devoted to technology subject matter where 3 days (15 periods) per year of technology day activities are included. For K4-5, 82 periods are integrated with natural sciences subject matter, where 4 technology days (20 periods) per year are included (Eurydice, 2016). At the secondary level, DT is a compulsory subject for grades 6-8 and is covered with a total of 140 school periods of 45 min over all three grades. The DT curriculum comprises four interconnected areas/categories, namely technical assets, technology for processing materials, work organisation and economics (Fakin, Kocijančič, Hostnik \& Florijančič, 2011). Students' DT outcomes from grades 6-8 are 
assessed against 119 standard benchmarks (46 in grade 6, 34 in grade 7 and 39 in grade 8). The very nature of DT, as it is presented within the curriculum, requires students to utilise and demonstrate their declarative (knowing that) and procedural (knowing how) cognitive knowledge. A substantial majority of benchmarks are positioned within the first three levels of the revised Bloom taxonomy: to know, to understand and to apply (Krathwohl, 2002), while higher order thinking relating to DT is rarely required. During the last two decades, no significant changes have been made to the structure and content of the DT curriculum to upgrade benchmarks geared towards enhancing advanced abilities entailing action, criticism, informed decision making, evaluation and management. Inappropriate DT benchmarks and their implementation in the classroom could jeopardise the level of technological literacy and technical creativity, which is crucial for enabling students to choose a future career relating to technical and engineering studies and jobs (Luckay and Collier-Reed, 2014; Yu, Lin, Han, \& Hsu, 2012). Nevertheless, Slovenian government proposed some changes to the educational system, aligned with European Union (EU) education policy, which are focused on strengthening links between education and business and industrial sector with (1) introduction of entrepreneurship, innovation and creativity in pre-university technology education, (2) establishing of advanced training centres as a part of school network, and (3) establishing systems which will enable technology teachers to develop professionally at EU level (EURYDICE, 2014).

Today, there are many strategies and styles for teaching, but technology teachers still strive for the traditional form, because it requires the least effort, the minimum time is spent in the class, and the results of the teaching are immediately visible as technological work (Norström, 2013). Moreover, a mismatch exists between students learning styles and teachers learning styles what might affect efficacy of teaching/learning. Learning styles as personal qualities influence the way of students' acting towards learning environment, material, peers, and teachers (Felder \& Brent, 2005). Several modalities of learning styles exist where students may act as (1) concrete or abstract learners, (2) active or reflective, (3) sequential or global thinker, (4) visual, aural, read/write preferences, (5) sensing or intuitive, (6) sociological preferences of learning, (7) environmental preferences, (8) emotional orientation, (9) perception of physical elements, and (10) psychological elements of hemisphericity (Hawk \& Shah, 2007). All aforementioned styles might affect students learning and their success at technology education and technology teacher must consider students learning styles also to instil creativity in technology education.

Technology education outcomes are more complex than only technological knowledge and knowledge about technology which is used along work where students carry out e.g., different embodiments, models, products by testing and retesting to get a prototype, which must be documented in a way of technical drawings, sketches, and photos. Technology teacher must be more competent than he/she was in the past, due to new rapidly changing technologies and only well trained and educated teacher might influence markedly student learning. As the most important, teacher subject matter knowledge, pedagogical content knowledge and teacher attitudes and self-efficacy strongly guide behaviour in the classroom (Rohaan, Taconis, \& Jochems, 2010). In last ten years Slovenian technology teachers are well trained and proper educated to cope with all technical and technological requirements. The other, very important aspect to be discussed is how to interpret technology education outcomes, and here, additional pedagogical, philosophical, and sociological view is needed to analyse the contexts what to teach and how to assess outcomes (Norström, 2013) as they are knowledge, attitudes and skills where the creativity 
is found to be an essential element of any learning process. Creativity is an ability to invent and be able to go beyond what is already known and it is also defined as the ability to create a solution for a poorly defined problem or as an ability to identify new problems (Jaarsveld, Lachmann, van Leeuwen, 2012). Cropley (2015) defined criteria for creative products as the basic outcome of technology and engineering education as: (1) novelty as an absolute prerequisite for creativity, (2) relevant and effective, (3) elegant, and (4) genesis.

Teacher's creativity and creative behaviour might affect students' personality to enhance their creativity (Avsec \& Šinigoj, 2016). It was found by Rohaan et al. (2010) that teacher's skills and self-efficacy along with their pedagogical content knowledge might affect students' attitudes. Students are interested in technological products, but their opinions on future careers in technical and engineering study and jobs are particularly positive (Ardies et al., 2015). Moreover, it was found, that interest for DT declines over study year, it appears more often for female students. Ardies et al. (2015) provided evidence that teacher instructions of DT when student see practical utility of science, parents' technical/engineering education, and presence of home workshops and technical toys, positively influence attitude towards technology. Yu, Lin, Han and Hsu (2012) found that interest for technology enhances technological identification which moderates future decisions for technical/engineering career. It was also revealed that interest for technology mediates technology curriculum while technology curriculum might affects decision for future career in technical/engineering jobs (Yu et al., 2012).

Students at technology education must develop disposition toward engaging in active role orientation, such as initiating change and influencing their environment until meaningful change occurs in the achievement of their goals, in contrast with passive people who just adapt to their undesirable circumstances (Kim, Hon, \& Lee, 2010). Student must act proactively, and along with a high level of self-efficacy and voice behaviour, make response to a problem situation or environmental context to complete the tasks. Proactive student more like to seek for an improvement in a process or product to improve efficiency: this is called technical creativity. Technical creativity also presents the degree to which a desirable product or process is realised (Taura \& Nagai, 2011). For creative activities of students at DT to whom a pragmatic set of values is assigned, the goal is inventiveness, which is an indispensable element of progress and that improves the quality of life (Szewczyk-Zakrzewska \& Avsec, 2016). Students ' positive affirmation to DT subject matter and technology itself, might be crucial for the translation of creative ideas into successfully implemented inventions first followed by innovations when the products/process are being commercialized (Rank, Pace, and Frese, 2004). Self-regulation and persistence behaviour successfully predict creative potential, while voice behaviour as constructivist self-learning process additionally enhances contextual performance (Rank et. al., 2004) which must be rather defined with performance-approach goals (Avsec \& Šinigoj, 2016). Evidence-based practise with a hands-on creation project allows students eliciting their prior-knowledge and experience to provide ideas for improving the current projects. This positive attitude might reduce participants' resistance to change and enhances interest, learning and creativity, when working on real-world projects (Avsec \& Šinigoj, 2016).

Students possess different experiences, perception and ability to study, to think, to process information, to perceive physical, virtual and social environment, different inclination for study, different scaffolding process, and different motivation what might 
distort designed learning process. To avoid this, a need for mapping students learning exists to improve their learning and creativity.

Despite of several studies to explore technology education, an effective and a clear visualization of predictors affecting creativity is still lacking. Therefore, the objective of this paper is to investigate how students' individual differences affect technical creativity as an outcome of technology education.

We contribute to the literature by providing evidence of an association between students learning styles, their experiences and attitudes toward design and technology, and the performance measured as creative potential in the context of the primary school DT subject matter learning environment. Especially, technology teachers, educators, and course designers in technology education can benefit from this.

\section{Methods}

We used an empirical research design to investigate weather students' learning styles and their attitude towards technology and engineering predict technical creativity in sixthand ninth-graders at primary school. The samples, instrumentation validation and specification, procedure and data analysis of our study are described in the following subsections.

The sample of this study was drawn from Slovenian primary school students. The three schools selected for this study were one from urban area, one from urban-rural area and one from rural area. Schools were selected on the basis of students' achievements in a national examination. The level of the selected school was regarded as average at the country level. Students' distribution across the sex, grade and type of school area is shown in Table no. 1.

\begin{tabular}{|c|c|c|c|}
\hline \multirow{2}{*}{ Primary School } & \multirow{2}{*}{ Grade } & \multicolumn{2}{|c|}{ Sex } \\
\cline { 3 - 4 } & & Male & Female \\
\hline \multirow{2}{*}{ I.C. Vrhnika } & 6 & 10 & 11 \\
\cline { 2 - 4 } & 9 & 12 & 7 \\
\hline \multirow{2}{*}{ Pivka } & 6 & 22 & 28 \\
\cline { 2 - 4 } & 9 & 30 & 16 \\
\hline Prestranek & 6 & 14 & 8 \\
\cline { 2 - 4 } & 9 & 10 & 9 \\
\hline Total & 6 and 9 & 98 & 79 \\
\hline
\end{tabular}

Table no. 1: The study sample structure with frequencies $(n=177)$.

For measuring student's attitude towards technology, a reconstructed 25 -item test of Students Attitude towards Technology of authors Ardies, De Maeyer, \& Gijbels (2013) was used. Slovenian adaptation of the test called The Technology and me survey which includes also questions on demographics (sex and age), and eight questions about family background, and home education background. These 25-items covered six constructs: (1) technological career aspirations (TCA)-4 items; (2) interest in technology (IT)-6 items; (3) tediousness towards technology (TTT)- 4 items; (4) technology across the sex (TS)-3 items; (5) consequences of technology (CT) -4 items; and (6) technology/engineering study is difficult (TD)-4 items. For the assessment, a 5-point Likert scale was used. The intervals 
of the scale together form a continuous type, from 1 (very unlikely) to 5 (very likely). Creativity of students was surveyed with test of Creative Thinking-Drawing Production (TCT-DP) (Urban, 2004). Students complete incomplete drawings in any way they like. Maximum score on test is 72 points assessed on fourteen criteria.

For surveying students' learning styles, recently developed Dynamic Learning Style Inventory (DSLI) was used (Szewczyk-Zakrzewska \& Avsec, 2016). The survey included questions on demographics, 95 questions on eight mode predictor variables with 36 subscales. Demographic questions were related to sex, age, and education level. DSLI was proved as valid and reliable enough instrument and successfully covers all eight modules of learning styles. For the assessment, a 6-point phrase completion scale was used as recommended by Allen \& Seaman (2007), and Dawes (2008). The intervals of the scale together form a continuous type, from 0 (very unlikely) to 5 (very likely). It does not present the mean, but ensures the comparability of continuous responses and produces better assumptions of parametric statistics (Hodge \& Gillespie, 2007) while avoiding bias.

Data was collected during real-world classroom in study year 2015/16. All three instruments were administrated in the same day, started with easy task to the intensive task. Technology and me test was performed first, followed by DSLI and as the last TCT-DP test was done. Individual testing for each test takes 10-15 minutes. The data were analysed with IBM SPSS (v.22). To support the reliability of tests, a Cronbach's $\alpha$ coefficient was used. We conducted an analysis of variance ANOVA to identify and confirm significant relationships between groups with an effect size calculated with $\eta^{2}$. The basic tools of descriptive statistics, and multiple regression analysis, were used.

\section{Results}

Our findings are reported as reliability information for instruments used, descriptive analyses of survey data, and variance and regression analysis with the effect size.

The Cronbach's coefficient alpha values, based on the sample of this study, indicated that the developed and upgraded instruments were highly reliable. Cronbach's $\alpha$ coefficient values for Technology and me survey and standardised TCT-DP test are shown in Table no. 2 .

\begin{tabular}{|c|c|}
\hline Survey: Technology and me subscales & Cronbach's $\alpha$ \\
\hline TCA-Technological career aspirations & 0.92 \\
\hline IT-Interest in technology & 0.74 \\
\hline TTT-Tediousness towards technology & 0.75 \\
\hline TS-Technology and sex & 0.91 \\
\hline CT-Consequences of technology & 0.76 \\
\hline DT-Technology difficulty & 0.69 \\
\hline Survey: $T C T-D P$ & 0.78 \\
\hline
\end{tabular}

Table no. 2: Reliability information for Technology and me survey subscales and TCT-DP test.

Reliability information for DSLI instrument is shown in Table no. 3, where an entire structure of DSLI instrument with all modalities and subscales is shown. 


\begin{tabular}{|c|c|c|c|}
\hline Module/dimension & Subscale & $\begin{array}{l}\text { Number } \\
\text { of items }\end{array}$ & $\begin{array}{l}\text { Reliability } \\
\text { Cronbach's } \alpha\end{array}$ \\
\hline \multirow{2}{*}{ Learning orientation } & Concrete (pragmatist) & 3 & 0.66 \\
\hline & Abstract (theorist) & 3 & 0.64 \\
\hline \multirow[t]{2}{*}{ Processing information } & Active (impulsive) & 3 & 0.78 \\
\hline & Reflective & 3 & 0.67 \\
\hline \multirow[t]{3}{*}{ Understanding/thinking } & Sequential & 3 & 0.76 \\
\hline & Cluster & 3 & 0.83 \\
\hline & Global & 3 & 0.77 \\
\hline \multirow[t]{2}{*}{ Perceiving information } & Intuitive & 3 & 0.72 \\
\hline & Sensing & 3 & 0.64 \\
\hline \multirow{11}{*}{ Physical and time } & Visual & 3 & 0.76 \\
\hline & Auditory & 3 & 0.68 \\
\hline & Read/Write & 3 & 0.70 \\
\hline & Tactile & 3 & 0.81 \\
\hline & Kinaesthetic & 3 & 0.84 \\
\hline & Requires intake & 2 & 0.83 \\
\hline & Does not require intake & 2 & 0.72 \\
\hline & Functions best in morning & 2 & 0.64 \\
\hline & Functions best in afternoon & 2 & 0.65 \\
\hline & Functions best in evening & 2 & 0.83 \\
\hline & Needs mobility & 3 & 0.67 \\
\hline \multirow[t]{3}{*}{ Sociological } & Learning alone & 3 & 0.69 \\
\hline & Peer oriented & 3 & 0.67 \\
\hline & Authority figures present & 3 & 0.66 \\
\hline \multirow{6}{*}{ Emotionality } & Self-motivated & 3 & 0.63 \\
\hline & Other-motivated & 3 & 0.70 \\
\hline & Persistent & 3 & 0.64 \\
\hline & Responsible & 2 & 0.66 \\
\hline & Nonconformist & 2 & 0.81 \\
\hline & Needs structure & 3 & 0.79 \\
\hline \multirow[t]{7}{*}{ Environmental } & Sound-needs quiet & 2 & 0.85 \\
\hline & Sound-acceptable & 2 & 0.85 \\
\hline & Light-needs much light & 2 & 0.64 \\
\hline & Light-needs low light & 2 & 0.71 \\
\hline & Needs cool environment & 3 & 0.67 \\
\hline & Seating design-formal & 2 & 0.81 \\
\hline & Seating design-informal & 2 & 0.72 \\
\hline
\end{tabular}

Table no. 3: Reliability information for DSLI across the subscales.

DSLI survey results are reported with $M$-mean and $S D$-standard deviation according to the category (subscale) of DSLI and only statistical significant $(p<0.05)$ differences between sixth- and ninth-graders $\left(n_{6 g}=93, n_{9 g}=84\right.$; respectively) are presented and 
discussed in the paper. As it was expected no significant differences $(p>0.05)$ were found between students in category of Learning orientation and Processing of information. Pragmatists, Theorists and Reflectors are almost evenly distributed, while a number of Active students is significantly lower $(M=3.16, S D=0.98 ; M=3.22, S D=0.90 ; M=3.20$, $S D=0.97 ; M=2.35, S D=0.95$; respectively). It was also found that sixth-graders are more sequential thinkers over the ninth-graders $(M=3.69, S D=0.98 ; M=3.41, S D=0.91$; respectively) while at perceiving information no differences were found. Still, we have more sensing rather than intuitive students $(M=3.44, S D=0.97 ; M=2.62, S D=0.93$; respectively). Physical and time preferences of the students seem to be different. Sixthgraders are more tactile in contrast with ninth-graders $(M=3.06, S D=0.95 ; M=2.83$, $S D=0.83$; respectively), prefer to learn in the morning and afternoon, and do not need intake of food and drinks as much they need this ninth-graders. It seems that the ninthgraders prefer to learn in the evening. Sociological aspect of DSLI revealed no significant differences $(p>0.05)$ between students. Both, they prefer peer learning, as prevailing way of social learning and scaffolding. Students in grade 6 are more other-motivated in contrast with students in grade $9(M=3.63, S D=0.97 ; M=3.36, S D=0.93$; respectively), but surprisingly more persistent $(M=3.75, S D=0.82 ; M=3.41, S D=0.91$; respectively). Sixthgraders in contrast with ninth-graders need quiet $(M=3.40, S D=1.11 ; M=2.88, S D=1.23$; respectively), more (intensive) light ( $M=3.50, S D=1.17 ; M=3.18, S D=1.29$; respectively), and they use formal furniture in the study room $(M=3.10, S D=1.31 ; M=2.65, S D=1.43$; respectively). Majority of aforementioned significant differences $(p<0.05)$ in students' learning styles were judged as a small to moderate expressed with a coefficient $\eta^{2}=0.02$ 0.1 (eta squared) as a measure of effect size.

Technology and me survey was aimed to investigate students experiences and perceptions of design, technology and engineering. Image no. 1 depicts students' attitude towards technology in Grade 6 and Grade 9 with a mid-point 3.

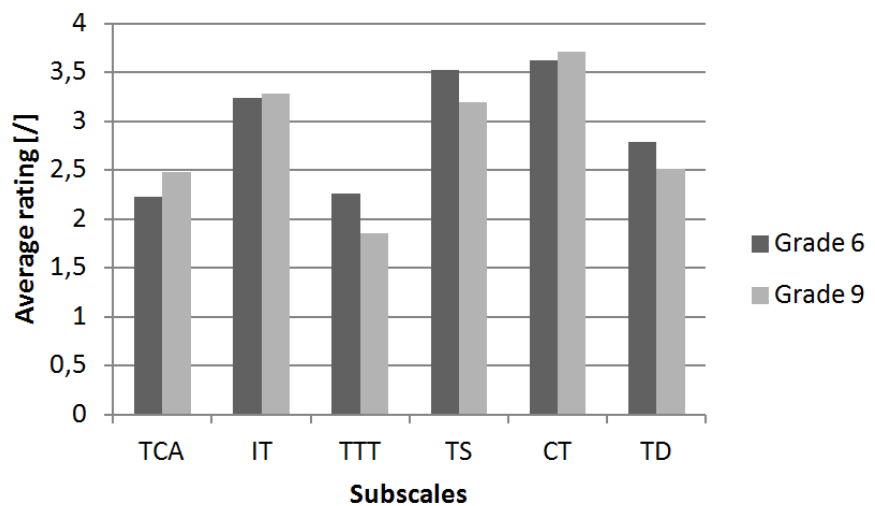

Image no. 1: Students' average rating on attitude towards technology across the grade of students with a mid-point 3 .

The general attitude is estimated about average. Technological career aspirations seem to be not enough developed. Students felt not motivated yet for further schooling of technical and/or engineering studies and professions. Students' interest for technology and 
engineering subject matter is about average, while both sixth- and ninth-graders perceived technology and engineering subject matter as under average regarding to the difficulty of the study itself. Positively, students perceived their tediousness towards technology as under average. Still, students perceived technology and engineering subject matter and profession as male domain, especially male students in Grade 6. Students have developed critical thinking ability and they perceived consequences of technology above the average.

Further descriptive analysis indicated that the test for homogeneity of variance was non-significant, meaning that the sample exhibited characteristics of normality required for analysis under the assumptions of the general linear model. The Levene's test for equality of variances achieved no statistical significance at survey $(p>0.05)$. The Levene's test confirmed that the study sample did not violate the assumption of normality, which confirmed that the sample is normally distributed. Using aforementioned into account, we found significant difference in students' perception only in category of TTT $(p=0.003<0.05)$ where sixth-graders are more tediousness toward technology, with a moderate effect size $\eta^{2}=0.05$; and at perceived TD, again sixth graders felt technology more difficult from their counterparts in Grade 9, with a small effect size $\eta^{2}=0.03$.

Gender differences in sixth- and ninth-graders attitudes towards technology are shown in Image no. 2.

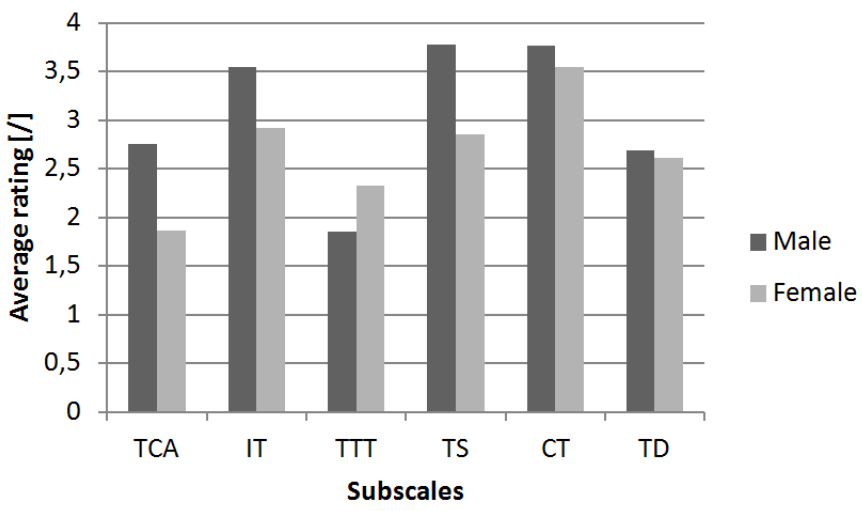

Image no. 2: Students' average rating on attitude towards technology across the sex with a mid-point 3 .

A study of the results gained with Technology and me survey across the sex, yielded some interesting findings. Male students are: (1) more interested in future careers in technical/engineering study and jobs $(p=0.00<0.05)$ with a large effect size $\eta^{2}=0.15$, (2) more interested in technology and engineering subject matter $\left(\mathrm{p}=0.00<0.05 ; \eta^{2}=0.13\right)$, (3) do not have a resistance towards technology $\left(p=0.00<0.05 ; \eta^{2}=0.07\right)$, (4) more convinced that technology/engineering is more male domain $\left(p=0.00<0.05 ; \eta^{2}=0.12\right)$, and (5) slightly more aware of the consequences of different technologies $\left(p=0.048<0.05 ; \eta^{2}=0.02\right)$. The measure of effect size $\eta^{2}$ means from 0.01 to 0.05 - a small effect, of 0.06 to 0.14 - medium effect, 0.14 and more - large effect (Cohen, Cohen, West, \& Aiken, 2003). 
Our study confirms stereotypical ideas concerning gender differences, especially, in attitude to have a technological career, and in interest for design and technology subject matter. It seems that current design and technology curriculum does not have positive effects on career aspirations. It appears that not motivate further changes in education, to have more female students in engineering education and not to waste future talents.

Students' creative potential was measured with standardized TCT-DP test. Table no. 4 shows students' results in one-shot creativity test where the maximum score on the test is 72 points.

\begin{tabular}{|c|c|c|c|c|}
\hline Sex & Grade & $M[/]$ & $S D[/]$ & $\mathrm{n}$ \\
\hline Female & 6 & 30.34 & 8.37 & 47 \\
\hline & 9 & 29.22 & 9.35 & 32 \\
\hline & Total & 29.88 & 8.74 & 79 \\
\hline Male & 6 & 27.78 & 9.54 & 46 \\
\hline & 9 & 28.73 & 9.19 & 52 \\
\hline & Total & 28.28 & 9.32 & 98 \\
\hline Total & 6 & 29.08 & 9.01 & 93 \\
\hline & 9 & 28.92 & 9.20 & 84 \\
\hline & Total & 29.00 & 9.08 & 177 \\
\hline
\end{tabular}

Table no.4: Students' scores in creativity TCT-DP test.

The Levene's test for equality of variances achieved no statistical significance at survey $F(1,175)=0.274 \quad(p=0.602>0.05)$. The Levene's test confirmed that the study sample did not violate the assumption of normality, which confirmed that the sample is normally distributed. ANOVA test of variances reveals no significant differences in creativity at both between sixth- and ninth-graders $(p=0.908>0.05)$ and across the sex $(p=0.245>0.05)$.

Multiple regression analysis was performed to see how much the independent variables could predict students' creativity. A multiple regression analysis was carried out, with the items of students' learning styles first following by attitudes towards technology as independent variables, and creative potential as dependent variable. The authors assumed a linear relation between independent (predictor) and dependent (criterion) variables, meaning that one would expect that increases in one variable would be related to increases or decreases in another. Only regression coefficients ( $\beta$-weights) with a significance of $p$ $<0.05$ were considered. Beta $(\beta)$ weights describe the relation between a predictor and a criterion variable after the effects of other predictor variables have been removed. They range from -1 to 1 ( 0 means no relation at all; 1 or -1 mean that variations in one variable can be explained completely by variations in another). When interpreting results, one must keep in mind that multiple regressions do not explain causes and effects but instead describes relations between variables or sets of variables. A summary of the multiple regression analyses is shown in Table no. 5 . 


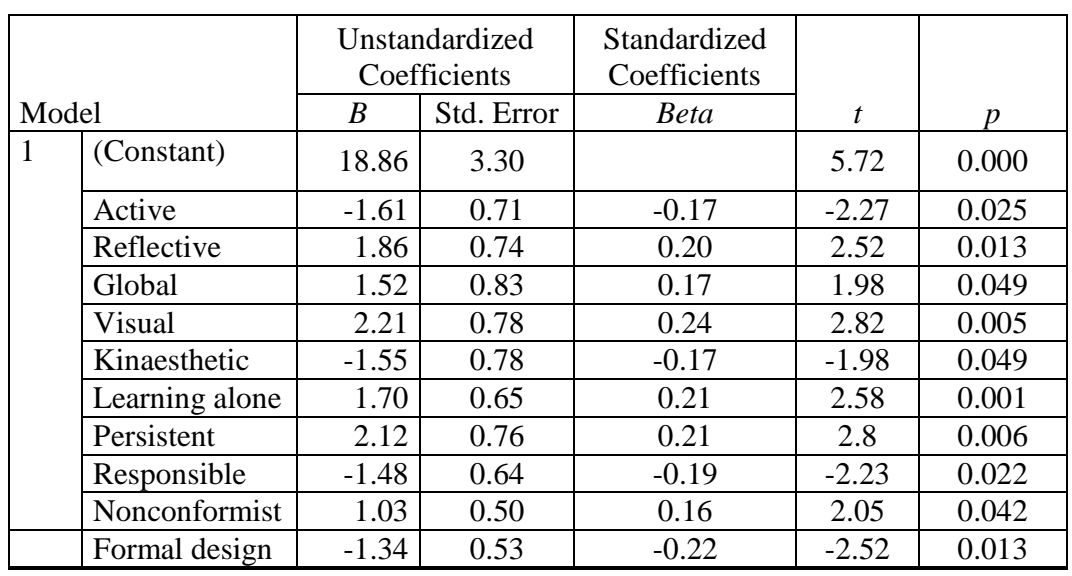

Table no. 5: Multiple regressions for predictor variables of learning styles where only significant $(p<0.05)$ predictors are encountered.

Creativity might be most positive affected with self-scaffolding learning along with persistence at learning of visual learners. This finding reveals the structure of our educational system, namely most students' tasks are designed in a way to cope with them alone, team work is not enabled, and learning objects are mostly visual nature. Learning tasks perhaps are not well designed; students took too much time on it, even tasks are not well structured to enhance students' creativity neither higher order thinking skills are enabled. This is connected with curriculum where a large majority of learning outcomes are designed in the level 1-3 according revised Bloom taxonomy.

Several negative estimates were found. Use of formal design of furniture as physical learning environment might not be successful motivator or enhancer of creative potential development, while impulsive and kinaesthetic learners are not ready yet to advance their creative potential in a way which was offered in the classroom. It points to the need of open learning environment where student's creativity is enhanced more than in traditional classroom. DT subject matter designers should consider this fact along with reduction of learning sets and half-elements used to have in classroom. It was already found that not so positive attitudes towards technology along with multiple constraints in design and technology learning tasks can douse students' creativity.

A multiple regression was used also to investigate how much attitudes towards design, technology and engineering could predict students' creativity as independent variable. Only two significant $(p<0.05)$ predictors were found, namely students' perception and awareness of consequences of technology as a strong positive $(\beta=0.34, p=0.000<0.05)$ and students opinion, that technical and engineering subject matter and jobs are in domain of males as negative $(\beta=-0.16, p=0.034<0.05)$. The explained variances were calculated using $R^{2}=$ 0.12 , where $R^{2}=0.02$ means a small impact, $R^{2}=0.13$ means a medium effect size, and $R^{2}=0.26$ presents a large effect size (Cohen, Cohen, West, \& Aiken, 2003).

Results revealed that students who had higher scores on consequences of technology, scored higher in creativity test. It seems that students with developed ability of critical 
thinking and decision-making advanced more in creativity during schooling. Students with lower level of cognitive ability felt DT as male domain, but their scores in TCT-DP test were lower from others. We expected more support for predictive value of attitudes towards technology. It presents motivation for the curriculum change, namely DT curriculum designers and technology teachers should include more critical thinking activities in every day lessons supported with real-world cases and rather than abstract they should make focus on concrete objects.

\section{Discussion}

The purpose of this study was to verify and understand the effect of individual differences on technical creativity in Slovenian K-9 students. The investigation of how students' learning styles, their attitudes towards technology affect creativity yielded some interesting results. Reliability of instruments used in recent study was found moderate to high what enable us with valid and predictable results.

Surprisingly, there are no significant differences $(p>0.05)$ in creative potential between sixth- and ninth-graders measured with TCT-DP test. Students' potential is judged to be low to moderate where a score range is from 0 to 72 points. Still we do not know if design and technology curriculum serves as creativity enhancer or only compensator for those with a low level of creative potential. From grade 6 to 9, mostly algorithmic subjects prevail, while design and technology subject matter is on side with only 140 periods in total and quite a lot of reproducing and simple working tasks are performed through the study years. Up to date, there is no subject designed yet in primary schooling with explicit goals to develop creative potential only.

Students learning styles significantly predict creative potential, where visual learners advanced more along with self-motivated and persistent students; hereby we confirm findings of Szewczyk-Zakrzewska \& Avsec (2016). Active students still have not well developed heuristics to get dynamism of learning styles. Students from grade 6 to 9 are given with technical sets where half-products and some raw material allow them to make simple designs after teachers' instruction and manuals. Perhaps, this type of evidence-based work does not enhance creative potential markedly. Technology education is not just technical work, but needs to be reconsidered due to complex learning outcomes and their assessment as was claimed by Norström (2013).

Technology is more present than ever, but students' attitudes towards technology and engineering are not particularly positive, hereby we confirmed findings of Ardies et al. 2015. Moreover, at education systems, where intensive technology education begin already in $\mathrm{K} 1$ and it is vertically connected to $\mathrm{K} 9$, students have more positive affirmations to future careers in technical/engineering study and professions (Eurydice, 2016; Yu et al., 2012). Students who are aware of consequences of technology scored significantly higher $(p<0.05)$ in creativity test, but still students in grade 6 and grade 9 did not feel comfortable with technologies, and technology identification is still lacking. Even more, technology perplexity sometimes decline students attitude away from and interest for technology and engineering subject matter might decrease.

\section{Conclusions}

This study indicated that individual differences in Slovenian K-9 students were significant predictors of creativity. Individual differences measured with learning styles and students attitude towards design and technology were significant $(p<0.05)$ predictors 
of technical creativity. Technology and engineering subject matter goals should be designed from a performance-approach rather than performance-avoidance goals. Due to many algorithmic designed subject matters, still we do not know if creativity goals in design and technology/engineering subject matter curriculum serve as an enhancer or compensator.

Design and technology curriculum for Slovenian students in grade 6-9 needs to be upgraded markedly. Firstly, content areas should be adjusted with standards for technological literacy where higher order thinking is enabled along with holistic development of skills on cognitive, psychomotor and interpersonal level, and attitudes what allows student to be successful in a given context. Secondly, a use of already prepared technical sets with half-products and pre-designed elements, aimed for reproduction work only, should be reduced and more evidence-based teacher activities should be introduced that students on-site see how the science rules are utilized in technology education. Thirdly, only well designed and highly structured technological problem solving activities should be included to enhance both social-constructivist learning and creativity which leads to future inventions. Fourthly, technology education should be presented to students clear, when a role, scope, aim and utilization of technology in society must be a crucial point to reduce perplexity and to advance on technology identification.

Since creativity was found as top three employability skills in 21 st century, technology education by its nature can shape technical creativity in students. Moreover, attitudes towards technology seem to be a key to the technical creativity development which leads to creative behaviour for innovative performance in classroom. Only well designed and highly competitive technology education curriculum enhances creativity, while several constraints along with algorithmic behaviours used in technology and engineering can douse creativity. To change students' beliefs and attitudes, several technological discrepant events are proposed during the lessons.

It is important to investigate the influence of the teacher further followed by how to define successful teacher where both learning outcomes and creative potential development of students should be considered. Moreover, to find more support for our results we will continue with research in Grade 7 and 8. Thus, we conclude domain of design and technology subject matter. To find more agreement, qualitative observations of lessons are necessary.

\section{Bibliography}

Allen, E., \& Seaman, C. (2007). Likert scales and data analysis. Quality Progress, 47,7, pp. 64-65.

Ardies, J., De Maeyer, S. and Gijbels, D. (2013). Reconstructing the pupils attitude towards technology - survey. Design \& Technol. Educ.,18, 1, pp. 8-19.

Ardies, J. De Maeyer,S., Gijbels, D. \& van Keulen, H.. (2015). Students attitudes towards technology. Int J of Technol and Des Educ, 25, pp. 43-65.

Avsec, S.,\& Jamšek, J. (2016). A path model of factors affecting secondary school students' technological literacy. Inter. J. of Technol. and Design Educ., 26, DOI: 10.1007/s10798-016-9382-z.

Avsec, S. \& Šinigoj V. (2016). Proactive technical creativity: mediating and moderating effects of motivation, World Trans. on Engng and Technol. Educ., 14, 4, pp. 540-545. 
Barbot, B., Besancon, M. in Lubart, T. (2016). The generality-specificity of creativity: Exploring the structure of creative potential with EPoC. Learning and Individual Differences, 52, pp. 178-187.

Cohen, J., Cohen, P., West, S. G., \& Aiken, L. S. (2003). Applied multiple regression / correlation analysis for the behavioral sciences. Mahwah, NJ: Lawrence Erlbaum, 736 p. ISBN-10: 0805822232.

Cropley, D. H. (2015). Creativity in engineering: Novel solutions to complex problems, San Diego: Acad. Press, 348 p. ISBN: 9780128002254.

Dawes, J. (2008). Do data characteristics change according to the number of scale points used? An experiment using 5-point, 7-point and 10-point scales. International journal of market research, 50,1, pp. 61-77.

Dostal, J., \& Prachagool, V. (2016). Technolgy education at a crossroads-history, present and perspectives, Journal of Technology and Information Education, 8, 2, pp. 5-24.

European Commission/EACEA/Eurydice (2016). Recommended Annual Instruction Time in Full-time Compulsory Education in Europe 2015/16. Eurydice - Facts and Figures. Luxembourg: Publications Office of the European Union.

European Commission/EACEA/Eurydice (2014). ET 2020 Education and Training stocktaking exercise:ET 2020 National Reports. Luxembourg: Publications Office of the European Union.

Fakin, M., Kocijančič, S., Hostnik, I. and Florijančič, F. (2011). Učni načrt. Program osnovna šola. Tehnika in tehnologija. Ljubljana, Ministrstvo za šolstvo in šport: Zavod RS za šolstvo. Retrived June 24, 2017 from:

http://www.mss.gov.si/fileadmin/mss.gov.si/pageuploads/podrocje/os/devetletka/predmet i_obvezni/Tehnika_in_tehnologija_obvezni.pdf

Felder, R.M. and Brent, R. (2005). Understanding student differences, Journal of Engineering. Education, 94, 1, pp. 57-72.

Hawk, T.F. and Shah, A.J. (2007). Using learning style instruments to enhance student learning. Decision Sciences J. of Innovative Educ., 5, 1, pp. 1-19.

Hodge, D. and Gillespie, D. (2007). Phrase Completion Scales: A Better Measurement Approach than Likert Scales? Journal of Social Service Research, 33, 4, pp. 1-12.

Jaarsveld, S., Lachmann, T., van Leeuwen, C. (2012). Creative reasoning across develpomental levels: Convergence and divergence in problem creation. Intelligence. 40,3, pp. 172-188.

Kallio, M. \& Metsärinne, M. (2017). How do different background variables predict learning outcomes? Int J of Technol and Des Educ, 27, 1, pp. 31-50. DOI:10.1007/s10798015-9339-7.

Kim, T., Hon, A.H.Y. and Lee, D. (2010). Proactive personality and employee creativity: the effects of job creativityrequirement and supervisor support for creativity. Creativity Research J., 22, 1, pp. 37-45.

Krathwohl, D. R. (2002). A revision of Bloom's taxonomy: An overview. Theory into Practice, 41, pp. 213-217.

Luckay, M. B., \& Collier-Reed, B. I. (2014). An instrument to determine the technological literacy levels of upper secondary school students. International Journal of Technology and Design Education, 24,3, pp. 261-273.

McGlashan, A. (2017). A pedagogic approach to enhance creative Ideation in classroom practise. Int J of Technol and Des Educ, doi 10.1007/s10798-017-9404-5. 
Norström P. (2013). How technology understand technological knowledge. Int J of Technol and Des Educ ,24, pp.19-38, doi: 10.1007/s10798-013-9243-y.

Rank, J., Pace V.L. and Frese, M. (2004). Three avenues for future research on creativity, innovation, and initiative.Applied Psychology: An Inter. Review, 53, 4, 518-528.

Rohaan, E. J., Taconis, R., \& Jochems, W. M. G. (2010). Analysing teacher knowledge for technology education in primary schools. Int $J$ of Technol and Des Educ. doi:10.1007/s10798-010-9147-z.

Szewczyk-Zakrzewska, A. \& Avsec, S. (2016). Predicting Academic Success and Creative Ability in Freshman Chemical Engineering Students: A Learning Styles Perspective. Int J of Eng Educ, 32, 2(A), pp. 682-694.

Taura, T. and Nagai, Y. (2011). Discussion on Direction of Design Creativity Research (Part 1) - New Definition of Design and Creativity: Beyond the Problem-Solving Paradigm. In: Taura, T. and Nagai, Y. (Eds), DesignCreativity 2010. London: SpringerVerlag, pp. 3-8.

Urban, K. K. (2004). Assessing Creativity: The Test for Creative Thinking-Drawing Production (TCT-DP) The Concept, Application, Evaluation, and International Studies, Psychology Science, 46, 3, 2004, pp. 387-397.

Yu, KC., Lin, KY., Han, FN. et al. (2012). A model of junior high school students' attitudes toward technology. Int J of Technol and Des Educ, 22, 4, pp. 423-436. doi:10.1007/s10798-011-9154-8. 